\title{
Place-lore in the Mélusine Narrative from Irish Tradition
}

\author{
Tiziana Soverino \\ Crumlin College of Further Education, Dublin, Ireland
}

Copyright (c) 2020 by Tiziana Soverino. This text may be archived and redistributed both in electronic form and in hard copy, provided that the author and journal are properly cited and no fee is charged for access.

\begin{abstract}
The Mélusine story is an international migratory legend ("Migratory Legend Suggested Irish Type", MLSIT 4081), whose essential ingredients are an Otherworld bride and an interdiction. First attested in medieval Irish literature (Macha), the narrative has survived in modern Irish folklore, with possible influences from the French Romance of Mélusine. This article examines both medieval written and modern oral forms of the narrative from a novel perspective: their place-lore dimension.
\end{abstract}

Key Words. Mélusine, Macha, Place-lore, Lakes, Goddess.

Resumen. La historia de Mélusine es una leyenda migratoria internacional ("Migratory Legend Suggested Irish Type" [Leyenda Migratoria Internacional de Sugerido Origen Irlandés], MLSIT 4081) cuyos ingredientes esenciales incluyen una interdicción y una esposa del más allá. Descubrida en primera instancia en la literatura irlandesa medieval (Macha), la narrativa ha sobrevivido en el folklore moderno irlandés con influencias posibles del romance francés de Mélusine. El presente artículo examina las formas escritas y orales de la narrativa desde una perspectiva innovadora: la dimensión de la tradición local.

Palabras clave. Mélusine, Macha, tradición local, lagos, diosa.

\section{Introduction}

The Mélusine legend (MLSIT 4081) is attested in modern oral tradition from Ireland and Wales, as well as in the medieval literatures of Ireland, Wales and France. The story is not unique to Ireland. Being attested in a number of traditions, it is a migratory legend (Almqvist, Crossing the Border 270). The narrative was transmitted through various media: medieval manuscripts, oral tradition, and popular magazines. According to this legend, a mortal marries a supernatural woman, on the condition that he will not break a certain interdiction. Their union is successful, until he forgets, or neglects, the taboo. The woman flees, often 
bringing the couple's children with her. The breaking of the taboo leads to a supernatural consequence. The imposition of the interdiction on the woman's part, and its breaking by the male protagonist, lies at the core of this story type according to Ó Súilleabhán and Christiansen (88), and Almqvist (The Mélusine Legend 15). This legend frequently includes explanations, either in the form of etymology, or of the origin of certain places, customs or dynasties. The narrative has recently attracted scholarly attention, both internationally (Urban et al) and in an Irish context, as an origin legend conveying an ambivalent attitude towards the supernatural (Darwin 135).

This article will set out to explore place-lore in the Mélusine narrative. The narrative has been investigated as part of a $\mathrm{PhD}$ dissertation which focussed more broadly on place-lore in Irish tradition. The emphasis on the place-lore elements of the narrative is justified by the recent revival in place-lore studies, noted by scholars such as Remmel (quoted in Valk and Sävborg 9). This scholarly interest in places has been caused by a shift from geography to human geography, with its emphasis on the relationship between human beings and their surroundings (Vastrik cited in Valk and Sävborg 10). The article will begin with an examination of the legend from Irish folklore (Part I); then, the focus will shift on medieval Irish literature (Part II). Finally, it will discuss the French romance of Mélusine (Part III) and will conclude with a comparison of the topographical elements of the narrative in different strands of tradition. While the article might have had a different structure - it could have been built around the types of relationships between a mortal and the supernatural - it is felt that organising the article from a geographical and chronological perspective makes it easier to follow.

\section{Part I: MLSIT 4081 in modern Irish oral tradition}

This story can be classified as a legend rather than as a folktale. Legends are very localised, adapted to specific settings (Tangherlini 375; 385). The Mélusine's setting is usually realistic; it frequently encapsulates a folk-belief; and its style is short and simple (Almqvist, The Mélusine Legend 15).

As regards the methodology adopted to find the narratives in the National Folklore Collection (NFC), the NFC index - available solely in hard copy - has been used. Of the four different Indexes, the one arranged according to Subject Matter was selected, since narratives from throughout the country were required, and it was not wished to confine the research to material collected by specific collectors, or provided by specific informants. Although it is not perfect, the presence of the NFC Index is vital. Unfortunately, however, only a small portion of the Subject Index was completed in the time of the Commission, between 1935 and 1971 (Almqvist 1977-9, 16), and the index remains a work in progress. The Subject Index is divided into headings, based on A Handbook of Irish Folklore, which was compiled in 1942 by Séan Ó Súilleabháin, informed by his first-hand knowledge of Scandinavian folklore archives, and of modern oral tradition in Ireland. The section of the Index dealing specifically with lakes and rivers, called "Water-Features" was investigated, especially the subsection on lakes which included the Mélusine legend (Soverino vol. II 24; 27).

A total of 27 versions of the Mélusine legend ${ }^{1}$ have been found from Irish oral tradition, mostly from NFC Manuscripts (MSS). The versions under consideration come from just six counties (Galway, Clare, Cork, Donegal, Monaghan and Kilkenny). This figure is sufficiently similar to that reported by Almqvist about this legend in Irish oral tradition. ${ }^{2}$ However, it is here argued, contra Almqvist, that even those versions of the legend from the Schools' Collection which had a close resemblance to written versions from popular magazines ("Clare 4-12" below) merit inclusion, because they come from oral tradition; once again contra Almqvist, even a legend with vague geography ("Kilkenny 1" below) is 
included, because, although the principal focus of this investigation is place-lore, it does not seem methodologically correct to ignore those specimens of stories which do not include specific place-lore. Also, only those versions of the legend which have been definitely collected from oral tradition are considered here: all versions from NFC MSS. To those, one version that comes from a published source has been added (Mac Cionaoith 2005, 10-12, "Donegal 3"), but only because the story was clearly collected from oral tradition, before being transcribed in a book. On the other hand, the magazine versions of the narrative have not been included in the table reported below, because they belong to the written realm. Nonetheless, they have been included in the bibliography, as it is likely that there was a substantial amount of overlap between oral and written versions of the story in $20^{\text {th }}$ century Ireland.

Since most of the Irish versions of the Mélusine legend - 17 out of 27 - are drawn from the Schools' Collection rather than from the Main Collection of the NFC, it may be useful to provide some background. The Schools' Collection scheme was undertaken in 19378 , in primary schools. Pupils aged between 11 and 14, from the 26 counties of the Irish Republic, contributed material. Their accounts are found in about half a million manuscript pages (Ó Súilleabháin, The Folklore of Ireland 13). Pupils were encouraged to interview neighbours (Ó Catháin, Súil siar 22), relatives and friends (Anonymous, p. 3). The scheme was accompanied by a booklet, intended as an aid to teachers and pupils; it included 55 general headings, each of which contained specific questions (Ó Catháin Súil siar 21). A number of these headings lent themselves to accounts of local places and place-names. The Schools' Collection is not without pitfalls; for example, since their folklore essays were marked by teachers, pupils might have felt encouraged to embellish their stories; also, stories of fantasy possibly have a great appeal for children. Finally, some aspects of tradition, such as adult themes, might have been glossed over. On the other hand, the Schools' Collection has the advantage of covering Irish- and English-speaking parts of Ireland equally; it thus covers areas of Ireland which have been neglected by professional collectors (Briody 68). Despite their limitations, both the Main Manuscripts Collection and the Schools' Collection are extremely rich sources of place-lore. If the two collections are used in conjunction, some of the limitations typical of each may be circumvented (Soverino vol. II 22-23).

The 27 versions of the Mélusine narrative considered here are as follows: 


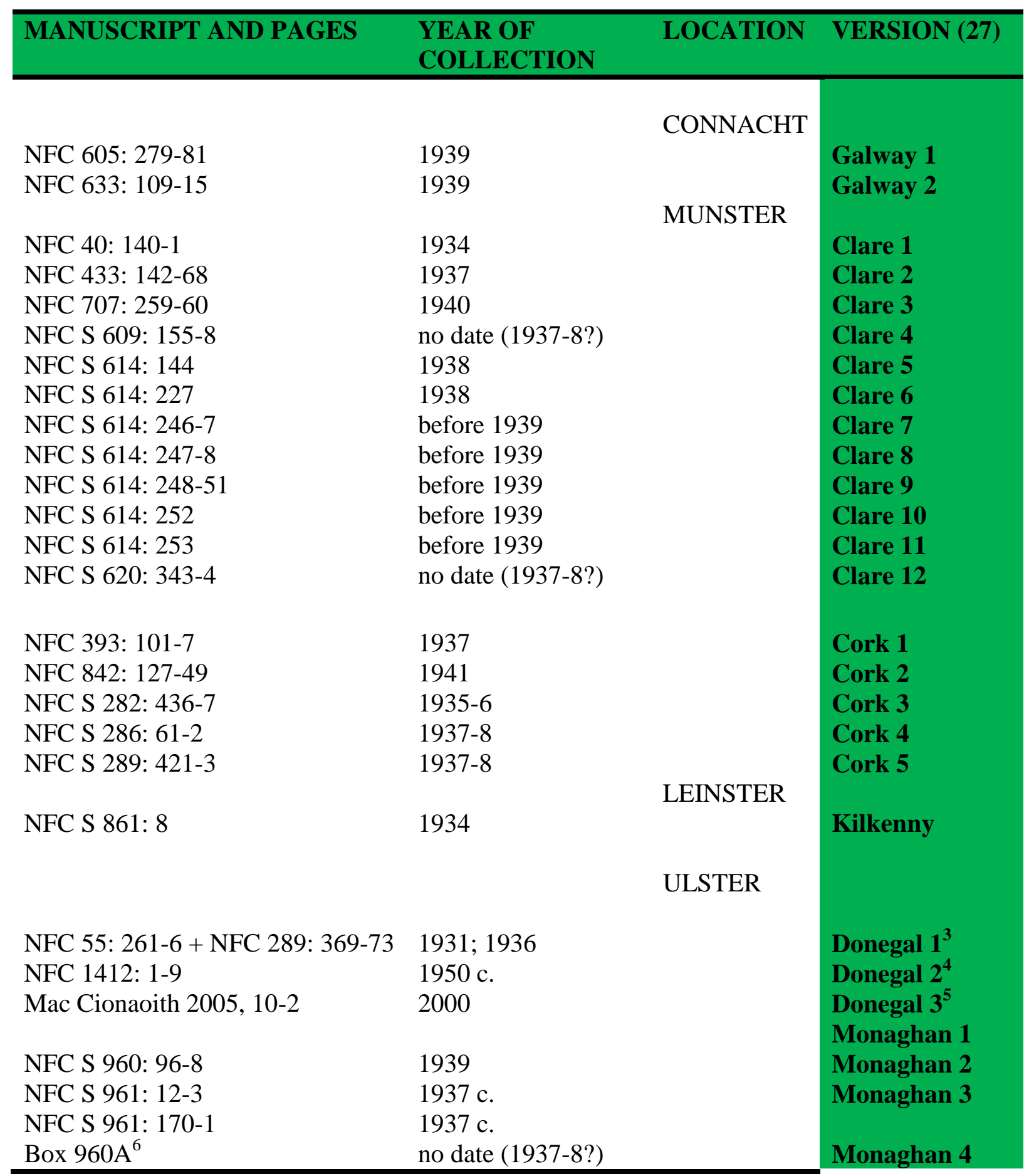

The relatively rare occurrence of this legend in Ireland may be partly explained by the fact that it is here attached to freshwater locations, the presence of which is necessary to have attracted this story (Almqvist, The Mélusine Legend 27); it should be noted that there are 5 versions of the Mélusine legend with provenance from landlocked counties, Monaghan and Kilkenny. Still, there are many lakes in Ireland about which there are apparently no traces of this legend. Almqvist further speculates that perhaps the greater popularity of "The Man who Married the Mermaid" legend in Ireland can explain why the Mélusine narratives are relatively rare (The Mélusine Legend 28): the two legends have broadly similar plots. It should be borne in mind that there are several hundred versions of "The Man who Married the 
Mermaid" legend, from nearly all coastal counties in Ireland; ${ }^{7}$ that legend was especially frequent in the Irish-speaking areas of Counties Mayo and Kerry (Almqvist, Of Mermaids and Marriages 4), from which no examples of the Mélusine legend have been reported. On the other hand, both "The Man who Married the Mermaid" legend (Almqvist, Of Mermaids and Marriages 4) and Mélusine have been attested from Counties Mayo and Donegal. The link between the two legends in Ireland and their distributions remain open to further investigation.

\section{Place-lore in the Mélusine legend from Irish folklore}

The place-lore displayed in the 27 versions of the Mélusine legends investigated here consists of 14 examples of place-transformation - of overflowing wells turning into lakes (Galway 2; Clare 4, 5, 6, 7, 8, 9, 11 and 12; Cork 1 and 3; Kilkenny 1; and Donegal 1 and 3) - and of three explicit place-name explanations (Clare 1, 4 and 5). It may not be out of place to discuss the versions which include place-name explanations first, since all them elucidate the appellation of a lake particularly connected to this legend: Loch Inse Cuinn or Inchiquin Lake, Co. Clare. In two cases (Clare 1 and 5) out of three, the male protagonist of the legend, whose name is Quinn, ${ }^{8}$ is said to follow his wife and children into the lake, and to vanish in it; according to the third (Clare 4), the lake is named after the man, "Lord Inchiquin", although he does not end his mortal life in it. These stories also specify that Quinn's castle is submerged by the lake. The supernatural woman, on the other hand, never lends her name to the lake. More surprisingly, the woman's name is never even revealed, perhaps since it does not serve any practical function (Almqvist, The Mélusine Legend 48).

Although only three versions explicitly state that Inchiquin Lake takes its name after the eponymous chieftain, it goes without saying, that in all those legends in which the name of the male protagonist is Quinn, and in which the place-name Lake Inchiquin is also mentioned (Clare 3 and 6, corresponding to Almqvist's The Mélusine Legend "Clare 1" and "Clare 3"), the explanation of that lake name is implied rather than spelt out. The correlation between the two would have been so obvious that it did not deserve specification.

The Mélusine legend is predominantly set in Co. Clare, even when told in other areas, ${ }^{9}$ for two principal reasons:

1. The story is associated with noble families of the area, such as the Quinns and the O’Briens (Ó hÓgáin 295; Kavanagh, The Mélusine Legend, Sinsear 77). ${ }^{10}$

2. It became particularly attached to Lake Inchiquin. ${ }^{11}$

More specifically, in Ó hÓgáin's opinion, the story would have been spread as a piece of proO'Brien propaganda: by claiming that an Otherworld lady, perhaps associated with the sovereignty goddess, had deserted their rivals, the Quinns, the O'Briens legitimised their own status (295). The same idea is reiterated by Kavanagh (The Mélusine Legend, Sinsear 72), and Almqvist (The Mélusine Legend 18). On the other hand, in the Irish examples of this story the dynastic connection looks unimportant, unlike in the French case: every time the offspring of the couple are mentioned in the Irish versions, it is specified that the supernatural woman brings her children to the Otherworld (ibid. 50; 276-7).

Inchiquin Lake also conspicuously features in early versions of the legend in widelyread popular magazines, in both the nineteenth and twentieth centuries: first, a version collected by Petrie, and based on oral tradition, published in The Irish Penny Journal in 1840, which probably made the story more widespread (Almqvist, The Mélusine Legend 18). ${ }^{12}$ Second, a number of versions also featured in Ireland's Own in the early twentieth century (Almqvist, The Mélusine Legend 63); however, it was only in 1938 that a version appeared in that magazine which seems to have influenced particularly strongly the folklore accounts. The influence of those versions of the legend on oral tradition has also been observed by Ó 
Danachair (39), as an example of a purely local legend, which has been impacted by printed sources.

Three Irish-language versions from Donegal and Galway - Donegal 1, 3 and Galway 2 - are also similar to this printed source. This parallel is surprising, given that those two versions from oral tradition are in Irish (Kavanagh The Melusine Legend, Diss. 12), while the Ireland's Own story is in English.

\section{Lake located on Inis Uí Chuinn, Co. Galway}

A version from Co. Galway (Galway 2) contains the aetiology of the formation of a small unnamed lake, located on Inis Ui Chuinn, or Inchiquin, an island in Loch Coirib. The similarities between the names Inchiquin Lake in Co. Clare and Inis Ui Chuinn in Co. Galway might have been enough to encourage the same story to be adapted (Almqvist, The Mélusine Legend 32). This transference of setting might have occurred, despite the absence of any explanation of the place-name Inis Ui Chuinn in this version of the legend (Galway 2). Even the male protagonist remains nameless. Place-name legends can easily be transferred from one place to another, as long as the two places have analogous names (Almqvist, The Mélusine Legend 267).

\section{Carnboy Lough, Co. Donegal}

While transference of legends can be made smoother by similarities in place-names, the parallel does not seem to be a requirement for local adaptations of narratives. The adaptation occurred for Carnboy Lough, or Loch an Charann Bhuí (Mac Cionaoith 200512, Donegal 3; presumably the same lake meant in Donegal 1).

Furthermore, the place-name explanation of Lake Inchiquin does not explicitly figure in the Ireland's Own version, in which both the chief and the woman remain unnamed-aside from the appellation of the latter as "The Lonely Lady". It is worth noting that the woman is nameless in this and other versions of the Mélusine legend from Irish oral tradition.

All the three versions from oral tradition in which the Mélusine legend is used to explain the origin of a lake other than Lake Inchiquin in Co. Clare come from Irish-speaking areas of the country, respectively from the Parish of Cong, Co. Galway (Galway 2); from Rann na Feirste, Co. Donegal (LA; Donegal 1 and 3); and the Muscraí area of Co. Cork (Cork 5), or its immediate surroundings. ${ }^{13}$ It is worth quoting the Mélusine legend from Rann na Feirste, as an example of a narrative containing the explanation of the origin of a lake (English translation from the original Irish):

The Queen of Loneliness

There was a chieftain who lived down on in An Charann Bhuí in the old times. His people had a big castle, and there was only him in his family [i.e. he had no brothers or sisters]. When they [his parents] died, they left everything to him. He was an honest, good-mannered, well-bred, honourable man, but when he was left on his own, he felt truly lonely. In his opinion he should try to find a wife. Well now, he did not know the young people of the locality very well, nor was he used to going out with young people. But anyway, he knew the local girls to see, and there was no girl in the community whom he wanted to ask to marry him.

There was a well of spring-water beside the castle, and he heard the old people and the story-tellers in houses on night-visits telling stories about a beautiful young woman who lived in a cave near the well; that she was to be seen early in the 
morning and late in the evening, going to the well to fetch a bucket of water. But if that were the case, even though the noble man heard those stories, he did not believe them. Well and good [literally, 'It was good and it wasn't bad'], on a spring evening, he was taking his cattle home. He was later than usual on this particular night, and when he was about to reach the castle, he saw the most beautiful girl he had ever laid his eyes on, leaving the well with a bucket of water. He ran after her, and grabbed her before she could get as far as the cave.

'Who are you,' he asked, 'and where do you live?'.

'I am the Queen of Loneliness,' she answered, 'and I live in An Charann Bhuî.

'Wouldn't it be better for the two of us to get together, and cheer each other up?'

'Oh,' she said, 'I can never marry any man.'

'Why?', he enquired, taken aback.

'It is this,' she said, 'that, once married to me, my husband would not be allowed to bring any man or woman related to him to An Charann Bhuí as long as I am here.'

'Isn't that odd?', he asked.

'It is odd' she said, 'but there's no cure for it. I must remain the Queen of Loneliness forever, and wouldn't it be hard for any man to share his life [?] with me and with loneliness?'

'Well', he answered, 'I'll be happy to put up with loneliness, if you marry me.'

'I will marry you for sure' she said, 'but think about it first, or you may regret it.'

The couple got married the following day, and they went to live in the castle in $A n$

Charann Bhui, and neither of them ever ventured in or out to any person, but they were attending to their own affairs. They spent their life there, happy and delighted, with neither of them uttering a rough or angry word to the other. Two children were born to them, a son and a daughter. The son looked like his father, and the daughter like her mother. As the years went by, the Queen of Loneliness did not change at all- she was as beautiful and comely as ever.

But if that were so, the nobleman was growing tired of the way he was, and he wished to go out again in the midst of people. There were horse-races to be held on the Sraith Bhán ['The White Ground'], and the noble man had a race-horse. He told his wife that he wanted to go to the races. She answered that he could go, but, if he loved her, he had to return home on his own. He said he would do so.

That day, he went to the races with his horse, and his horse won the races that day. The races lasted three days, and the horse of the nobleman won all three days. People started to gather around him in order to praise him.

'Your wife will be delighted when you go home'.

'She will be', said another person, 'provided that he has a wife at all.' 'Oh', he answered, 'my wife is the fairest woman in Ireland.'

'Well,' they said then, 'we must see her before we believe you'.

The nobleman had a sudden fit of anger, and he asked them to come with him. $\mathrm{He}$ did not think at all about the promise. When they arrived near the castle, he asked them to wait outside. He went into the castle, he brought out his wife and children, and he left them standing on the river-bank, but, in the moment it takes to clap your hands together, the three of them jumped into the river, and nobody has ever seen them since.

The nobleman's heart broke with sorrow. The people started to take pity on him, because they knew that they were to blame for it. The water rose high, and it spread over the fields until it covered the castle, and there is a lake in that place ever since, a lake which they call Loch an Charann Bhuí ['The Lake of the Yellow Moor/Cairn']. Knowledgeable people who live in this area say that on a fine summer evening, the 
shadow of the castle can be seen in the water, and three white swans swimming... around the lake. The nobleman repented, and he spent the rest of his life sad and lonely in An Charann Bhuí in Donegal without going in or out to anybody, but attending to his own business. (Mac Cionaoith 10-2; collected in March 2000)

This legend mentions three water landmarks, and explains the formation of one: a well, near which the nobleman meets the supernatural woman; a river, into which the woman and her two children jump when her husband breaks the prohibition; and a lake, Loch an Charann Bhuí, whose formation is explained as part of the vengeance by the supernatural. The origin of the river is left unexplained. When the man infringes the injunction, the supernatural world reacts not only by depriving him of his wife and offspring, but also by causing a dramatic landscape transformation.

To return to the distribution of those legends which include place transformation, an apparently obvious reason for the distribution - that the Irish language is key to understanding many place-names - does not apply, since in all sets of legends (Galway 2, Donegal 1 and 3, and Cork 1), it is only the origin of the lakes themselves, rather than their names, which are explained.

An alternative explanation is thus necessary: we may postulate that, in Irishspeaking areas communities had, and still have, a particularly hard-wired sense of place, which sufficed to cause the adoption of the Mélusine legend. The idea that place-name explanations belong more to the Irish-speaking areas than to the English-speaking parts of Ireland was expressed, for instance, by Ó Súilleabháin (Irish Oral Tradition 55-6), and by the poet Nuala Ní Dhomhnaill (41). Of course, Irish Folklore Commission collecting policies, which focussed predominantly on the Irish-speaking areas of the country (Almqvist, The Irish Folklore Commission 13; Ó Catháin 146), may be partly responsible for this.

\section{Part II: the Mélusine story in early Irish literature}

It is very possible that the core of the legend was originally Irish, since the oldest attested written version comes from early medieval Irish literature.

The story, of possible ninth-century date, exists both as an independent tale, Noinden Ulad (NU), "The Debility of the Ulstermen", and as texts of the Dindshenchas ("Lore of High/Notable Places") collection. The Dindshenchas provides (pseudo)-etymologies of about two hundred place-names. It is an example "of encyclopaedic learning" (Ó Fiannachta 91) and formed part of the curriculum of poets (Gwynn vol. V 92).

Since the story of Macha is deeply associated with the place-name Emain Macha, background details on Emain Macha itself may be useful. Emain Macha, or Navan Fort, was no ordinary place. On the contrary, it was a location of great ceremonial importance. Located only five kilometres from Armagh city (Raftery 74), on a hilltop affording a commanding view, it was used from the Neolithic, to the Bronze and Iron Ages, and later, for both habitation and burial (ibid. 75). The most spectacular phase dates to the Iron Age, when a single large elaborate circular structure was built and used (ibid.). Navan Fort was a key ceremonial place, and Macha might have been the sovereignty goddess said to legitimise kings there (contra Toner 82).

NU is one of the introductory tales to Táin Bó Cúailnge, "The Cattle-Raid of Cooley". Táin Bó Cúailnge "is the longest and most important heroic tale of the Ulster cycle" (O'Rahilly ix), focusing on the battle between the Ulstermen and the Connachtmen. NU features the basic events also recounted in the Dindshenchas of Armagh (Rennes Dindshenchas 94; Edinburgh Dindshenchas 61; Metrical Dindshenchas iv:124-31) and Emain Macha (ibid.308-11). In some versions of the tale, however, the woman's name is 
unspecified, ${ }^{14}$ and the place-name explanations are absent (Hull 28-38). The principal concern of the author of this tale was to explain the origin of the mysterious debility of the Ulstermen. It furnishes the rationale as to why, in the Táin, Cú Chulainn must defend the province of Ulster alone, while the Ulster people are in the throes of the debility (Nagy 216). A synopsis of NU is provided here.

Crunnchu is a wealthy Ulster peasant, ${ }^{15}$ and a widower. He is visited by a young woman, who, without uttering a single word, does all the housework, sleeps with Crunnchu, and becomes pregnant. Meanwhile, the peasant's wealth grows. But one day, Crunnchu goes to a great assembly held by the Ulstermen; his wife warns him not to go, since, should he mention her name, their relationship will end. He promises her that he will not say anything. At the assembly, however, Crunnchu boasts that his wife would be swifter than the royal horses. He is immediately compelled to bring his wife to race against those two steeds. She is forced to do so, wins the race, and gives birth to twins. Because of the way she has been treated, Macha lays a curse on the Ulstermen, who will be affected by labour-like pain in times of danger (Hull 28-38).

The origin and nature of the female protagonist of the story, Macha, remain controversial. According to scholars such as Sterckx and Mac Cana, she shares some attributes with the continental Celtic goddess Epona, and the Welsh Rhiannon (Mac Cana, The Irish Analogues 157). Epona, Rhiannon and Macha are all connected to horses, fertility and sovereignty. However, as remarked by Toner, the woman remains nameless in the oldest version of this tale (85); thus, her name and character may be a late medieval invention, extracted from the place-name Emain Macha (ibid. 82). Inventing eponymous characters from pre-existing place-names, solely with the aim of explaining toponyms, is a typical modus operandi of Early Irish literati. For instance, a female character named Dub, "Black", is probably derived from the place-name Dublinn, "Black Pool", in the Dindshenchas (Rennes 26; Bodleian 38; Metrical iii: 94-5). Yet, an alternative interpretation of the absence of the female protagonist's name in the oldest redactions of NU is possible. When writing about the Mélusine legend in modern oral tradition, Almqvist emphasises that the name of the Otherworld woman is similarly left untold because it does not serve a purpose (The Mélusine Legend 48). The same idea may be extended to NU: its rationale was to explain the origin of the Ulstermen's debility, not to elucidate place-names. Regardless of whether Macha was a pagan goddess or a character extrapolated from a place-name, she is associated with Navan Fort, a "royal site" of the Iron Age. In view of the topos of sovereignty goddesses legitimising kings in Early Irish literature, it is likely that Navan Fort commemorated a sovereignty goddess. Or at least it was consciously named after a woman by medieval literati.

As opposed to NU, the main focus of the Dindshenchas was to explain the origin of toponyms; the name of the female protagonist becomes central to elucidate the place-names Ard Macha (Armagh), Mag Macha (the plain around the city of Armagh, Onomasticon Goedelicum) and Emain Macha (Navan Fort, Co. Armagh; Rennes Dindshenchas 94; Edinburgh Dindshenchas 61; Metrical Dindshenchas iv: 124-31).These texts contain the explanations of multiple toponyms which include the personal name Macha, by commemorating three different characters, all named Macha. Only one of these characters, the woman who races against horses, concerns us here. The story is essentially the same as in NU. In all Dindshenchas texts the place-name Ard Macha is derived from the eponymous woman, who dies nearby and who is buried there.

The story of Macha's race occupies a privileged place in Early Irish literature: first, because it is the raison d'être of the numerous single combats between Cú Chulainn and his enemies in the Táin; and presumably also because of the importance of Navan Fort as a pagan ritual site. In the medieval literature, Macha is clearly associated with horses, and links between horses and kingship rites are attested in Irish tradition. Horse races also occur in the 
versions of the story from modern Irish folklore. On the other hand, horses do not feature in the French version of the narrative. It is time to turn our attention to the French Mélusine.

\section{Part III: the French connection}

According to Mac Cana, from its supposed Irish origin, the Macha/Mélusine narrative probably entered France through Britain and Brittany (The Irish Analogues 150-1). It is possible that the Irish brought the story of Macha with them abroad: medieval Irish scholars travelled widely throughout Europe, using the network of monasteries they founded. For example, Donatus of Fiesole, near Florence, made a name for himself abroad (Ó Cróinín 222). Also, the Macha/Mélusine legend might have developed from a common Celtic belief in goddesses associated with water, once held in both Gaul/France and Ireland, e.g. the goddess Sequana at Fontes Sequanae, near Dijon (Green 139-40). The borrowing might have also been facilitated by the common heritage of Celtic languages.

Le Roman de Mélusine ou l'Histoire de Lusignan by Jean d'Arras, was written in the fourteenth century for the duke Jean de Berry and his sister, in order to legitimise the claims for a supernatural ancestress made by the Lusignan family (Le Goff 7, 10). The synopsis of the French Mélusine by d'Arras goes as follows:

Raymondin's wealth prospers following his marriage to Mélusine. Mélusine has promised to remain at Raymondin's side, as long as he adheres to his promise: not to see her on a Saturday, when half of her body turns into a snake. When Raymondin tries to get possession of some of his cousin's land, a fountain miraculously turns into a river (51). Mélusine and Raymondin have eight male children, who conquer lands for themselves (75227). On one occasion, however, Raymondin breaks his promise, and discovers her serpent's tail. As a result, Mélusine has to leave (253). While doing so, she turns into a serpent. The marks left by that serpent when leaping from the window are said to be still visible on the stone just outside the window of the castle of Lusignan in Poitou (257).

The French romance was written by Jean d'Arras with a political purpose in mind: by depicting Mélusine as the ancestress of Jean de Berry, the writer legitimised the latter's claims to the territory of Poitou (Péporté 76-7) and to more exotic places such as Cyprus (Bouloumié and Béhar 8). However, the core of the story is that the couple's marriage is based on the respect of an interdiction; exactly as in Irish tradition. The myth of Mélusine has been studied in an international context, especially in French and German. Scholars have interpreted the figure of Mélusine in different ways: for example, Le Goff interprets her as a maternal figure, and as a pioneer, who brought economic wealth and built castles (219). Her character is laden with ambiguity, which may stem from the ambivalent character of both snakes and women. For instance, in ancient Greece, the serpent was a symbol of prosperity and fertility; by contrast, according to Christianity, the serpent is a tempter, which lured Eve to the Original Sin (Boulumié and Béhar 9). More recently, the story of Mélusine has been interpreted from a feminist perspective: the French romance can be said to challenge the male-centred medieval society in which it was written, because of its emphasis on male weakness, when Raymondin breaks his promise, as bringing about destruction (Lewis 25). Similarly, according to Urban, Mélusine's half-human, half-snake body represents the dangers of feminine power, and her expulsion from the human world a reflection on the conflicting demands imposed upon women (43-4).

The French romance is still very much tied to specific places. It contains two major place-lore items: a transformation from fountain to river (d'Arras and Perret 51); and the marks of the serpent, on a stone near the Lusignan castle (ibid.257). Mélusine is met near a fountain (ibid.38-44). Likewise, in Irish oral tradition, the supernatural woman is often encountered at a well. The transformation from fountain to river, also found in the romance 
by d'Arras - albeit as a supernatural help for him to obtain more land (d'Arras and Perret 51), rather than as a punishment - may be connected to the motif of the overflowing well associated with the Mélusine legends in modern Irish folklore.

\section{Discussion and conclusion: the Mélusine legend and place-lore in Irish tradition}

The Mélusine legend in Irish tradition is deeply connected to place-lore.

Place formation and transformation play a much bigger role in the Mélusine legends from modern Irish oral tradition than in the medieval Macha story. The latter emphasises place-name etymologies rather than place formation and makes no reference at all to water. The reasons for the much higher profile of place formation in the modern oral versions may be various: lakes are often associated with the supernatural; therefore, a supernatural origin for them is likely. Second, women, perhaps pagan goddesses, were linked to water landmarks in Celtic religion (Mac Cana, Celtic Mythology 48; Green 129). According to medieval tradition, the River Bóann/ Boyne took its name from the eponymous character, probably a pagan goddess. The river is said to have come about when Boyne deliberately breaks a prohibition, or as a punishment for extra-marital intercourse (RDinds. 19; Bodl. Dinds. 36; Met. Dinds. iii; Lucius Gwynn 201-38). The Boyne may be considered a fertility goddess; similarly, Macha had links with fertility in the medieval literature. When it comes to the modern Irish Mélusine, however, matters are more complicated: while she does bear children to her husband, they usually disappear with her into the lake. The land is not barren as a result; however, a lake appears to replace dry land. The motif of the covered well is common in Irish tradition (Ó Duilearga 252). There is a legend similar to the Mélusine, provisionally called "The Overflowing Well Legend", which occurs 53 times in the NFC (Soverino vol. II 32). The core is: a supernatural well is regularly used by people. They are aware that the lid must always be replaced after use, as otherwise its water may overflow. Inevitably, somebody - often a woman - forgets or neglects to do so. The well bursts, giving rise to a lake or river, and often drowning people (Soverino vol. II 30-1). While there is some overlap between the Mélusine and the Overflowing Well Legends, it is argued here that they are two separate narratives.

A comparison of the medieval Macha story and of the Mélusine legend in modern Irish oral tradition should be enlightening:

\begin{tabular}{|l|l|}
\hline MEDIEVAL MACHA STORY & MODERN MÉLUSINE STORY \\
\hline Male protagonist: wealthy peasant, widower. & $\begin{array}{l}\text { Male protagonist: gentleman, never married } \\
\text { before. }\end{array}$ \\
\hline $\begin{array}{l}\text { Woman enters Crunnchu's house on their } \\
\text { first meeting. }\end{array}$ & Woman encountered at a well/fountain. \\
\hline $\begin{array}{l}\text { She is pregnant with twins when her husband } \\
\text { breaks his promise. }\end{array}$ & $\begin{array}{l}\text { She has children before her husband breaks } \\
\text { his promise. }\end{array}$ \\
\hline $\begin{array}{l}\text { Horse-races are the setting of taboo } \\
\text { infringement. }\end{array}$ & $\begin{array}{l}\text { Horse-races are the setting of taboo } \\
\text { infringement. }\end{array}$ \\
\hline She races against royal horses and wins. & She does not go to the races. \\
\hline $\begin{array}{l}\text { Supernatural revenge: debility of the } \\
\text { Ulstermen. Consequence: naming of Emain } \\
\text { Macha, Ard Macha and Mag Macha. }\end{array}$ & $\begin{array}{l}\text { Supernatural revenge: overflowing of well } \\
\text { and formation of lake. }\end{array}$ \\
\hline \begin{tabular}{l} 
She dies as a result of the race. \\
\multicolumn{2}{|l|}{ She is lost to the mortal world: she jumps } \\
into the well, bringing her children with her.
\end{tabular} \\
\hline
\end{tabular}


Both the explanation of the origin of the Ulstermen's debility and the explanation of the origin of lakes are rationalised as the supernatural revenge or reaction of the Otherworld, when the woman's husband breaks the taboo. The etymology of Emain Macha and surrounding places, on the other hand, is not elucidated as a deliberate action on Macha's part. Rather, it is presented as the commemoration of the demise of the woman, and of her giving birth to twins (emon) in that location.

In ancient and modern versions of the story alike, place-lore may thus be considered a manifestation of the conflictual relationship between man and the supernatural. In many religions and worldviews, there is the idea that man must respect specific boundaries, and must not break prohibitions, in his dealings with the supernatural and with God or the gods. The same idea occurs in other legends, such as the Water-Horse Legend (Almqvist, Waterhorse Legends 113-4); and in religions such as Christianity, where Adam and Eve live in perfect harmony in the Garden of Eden, until they break the taboo and eat from the Tree of Knowledge (Genesis 3:1-7). Similarly, according to pagan Greek religion, human beings are not affected by illnesses or evil until an excessively curious woman opens Pandora's box (Powell 117-9). A key message in folklore and some religions is thus to respect specific boundaries between man and the supernatural or the divine. Failure to do so is extremely risky, and place-formation is a by-product of it. As with legends in general, "human misdeeds trigger the dramatic reactions of places" (Valk and Sävborg 9). Legends like this functioned as a map of behaviour, reminding people of what they should not do (Gunnell 15).

\section{Notes}

1 For classification purposes, these legends have been arranged in the attached table according to their provenance rather than according to their settings, in contrast with the method used by Almqvist (The Mélusine Legend 61-2).

2 Almqvist only considers 24 examples of that narrative as being attested in the country, including printed sources (The Mélusine Legend 24).

3 "Donegal 1" is formed by two entries ("a" and "b"), considered a single item because they were told by the same storyteller, as suggested by Almqvist (The Mélusine Legend 62).

${ }^{4}$ Printed in Ó hEochaidh, Sídhe-Scéalta, Béaloideas 23 (1954):161-6, and in Ó hEochaidh, Síscéalta ó Thír Chonaill, Fairy Legends from Donegal: 292-303. Particularly similar to the medieval Macha story.

${ }^{5}$ Collected by, and printed in Mac Cionaoith 2005:10-2, from Bríd Anna Ní Bhaoill, Rann na Feirste.

${ }^{6}$ Collected by schoolchild Agnes McAree (the copybooks inside the boxes do not contain page numbers; therefore, the name of the pupil who collected the story is here specified, as the only clue to identify the story).

${ }^{7}$ For a distribution map of "The Man Who Married the Mermaid" in Ireland, see Patricia Lysaght, The Banshee. The Irish supernatural death-messenger (1986) 161.

${ }^{8}$ For consistency, the name of the lake is spelled "Lake Inchiquin" throughout this article, while the name of the chieftain is spelled "Quinn", although the form "Quin", with only one n, is also used by tradition-bearers.

${ }^{9}$ In one case (Cork 3), the legend is probably set in the Lake Inchiquin area of Co. Clare even if told in some other region of Ireland. Cork 3, collected in Co. Cork, presumably accounts for the formation of Lake Inchiquin, Co. Clare. While the names of the well and the lake are left unspecified, the story is entitled "Lord Inchiquin", and we may thus think that the water-features in question are located in the Inchiquin area of Co. Clare. Caution is however best used, since there is a townland named Inchiquin in Co. Cork also, but it is located at a substantial distance from the place of collection of Cork 3 (Logainm.ie, henceforth LA). It thus seems more likely that the Inchiquin mentioned in Cork 3 is Lord Inchiquin of Co. Clare.

${ }^{10}$ In more than half of the versions set at Inchiquin, the O'Briens are specifically mentioned as the guest the male protagonist - mostly a Quinn - is forbidden from bringing home (Almqvist, The Mélusine Legend 30).

${ }^{11}$ Clare 1-12. 
${ }^{12}$ The same narrative also appears in The Ordnance Survey Letters, by O'Donovan. However, that source is unlikely to have given rise to later versions, because the letters were not widely read (Almqvist, The Mélusine Legend 18).

${ }^{13}$ The latter legend (Cork 1), comes from Gortloughra, which is located in the Parish of Kilmocomoge, Barony of Bantry, Co. Cork (LA). That townland is situated only seventeen kilometres from Ballingeary (Google Maps), which is currently classified as belonging to the Muscraí Gaeltacht of south-western Cork (www.udaras.ie/en/an-ghaeilge-an-ghaeltacht/an-ghaeltacht/corcaigh/, accessed on $30^{\text {th }}$ September 2013). It is possible that in the 1930s, when this legend was collected, the Irish-speaking area of Co. Cork extended beyond its current boundaries, to include Gortloughra.

${ }^{14}$ Surprisingly, the woman's name is not mentioned at all in The Book of Fermoy and in The Yellow Book of Lecan. On the other hand, the woman is named Macha in Harleian 5280, and in a gloss in Stowe 869 (Hull 30). The gloss, however, seems to be a later addition (ibid. 3).

${ }^{15}$ In the medieval tale, Crunnchu is a low-status peasant, which is untypical of the Ulster cycle (Mac Cana, The Irish Analogues 154); whereas in the French Mélusine, and in modern Irish oral tradition, the mortal husband of the supernatural woman is very high-status (Almqvist, The Mélusine Legend 29).

\section{Works Cited}

Almqvist, Bo. "The Irish Folklore Commission: Achievement and Legacy”. Béaloideas 45-47 (1979): 6-26.

"Crossing the Border. A Sampler of Irish Migratory Legends about the Supernatural". Béaloideas 59 (1991): 209-78.

. "Waterhorse Legends (MLSIT 4086 \& 4086B): The Case for and against a Connection between Irish and Nordic Tradition”. Béaloideas 59 (1991): 107-20.

. "Of Mermaids and Marriages. Seamus Heaney's 'Maighdean Mara' and Nuala Ní Dhomhnaill's 'an Mhaighdean Mhara' in the Light of Folk Tradition". Béaloideas 58 (1990): 1-74.

. "The Mélusine Legend in the Context of Irish Folk Tradition". Béaloideas 67 (1999): 13-69.

Anonymous. Irish Folklore and Tradition. Dublin: The Department of Education, 1937.

Bouloumié, Arlette and Béhar, Henri. Mélusine: Moderne et Contemporaine. Lausanne: Editions L'Age d'Homme, 2001.

Briody, Mícheál. The Irish Folklore Commission 1935-1970. Helsinki: Studia Fennica Folkloristica, 2008.

Bunachar Logainmneacha na hÉireann. 5 April 2020. http://www.logainm.ie

D'Arras, Jean. Le Roman de Mélusine ou l'Histoire des Lusignan. Trans. Michèle Perret. Paris: Stock, 1979.

Darwin, Gregory. "On Mermaids, Meroveus, and Mélusine: Reading the Irish Seal Woman and Mélusine as Origin Legend". Folklore 126.2 (2015): 123-41.

Green, Miranda. The Gods of the Celts. Thrupp, Gloucestershire: Sutton Publishing, 2004 (1986).

Gunnell, Terry. "Introduction". Legends and Landscape. Ed. T. Gunnell. Reykjavik: University of Iceland Press, 2008, 13-24.

Gwynn, Edward. The Metrical Dindshenchas (I-V). Dublin: Royal Irish Academy Todd Lecture Series Vols VIII, IX, X, XI, and XII, 1903-35.

Gwynn, Lucius. “Cináed úa Hartacáin's Poem on Brugh na Bóinne”. Ériu 7 (1914): 210-38.

Hogan, Edmund. Onomasticon Goedelicum. Dublin: Hodges Figgis, 1910.

Hull, Vernam. "Noínden Ulad: the Debility of the Ulidians". Celtica 8 (1968): 1-42.

Kavanagh, Jean. The Melusine Legend (MLSIT 4081) in Irish Folk Tradition. Third Year Diss., University College Dublin, 1993.

Kavanagh, Jean. “The Mélusine Legend in Irish Folk Tradition.” Sinsear 8 (1995): 70-82. 
Le Goff, Jacques. "Préface”. Le Roman de Mélusine ou l'Histoire des Lusignan. Ed. and trans. J. D'Arras and M. Peret Paris: Stock, 1979.

Le Goff, Jacques. Time, Work and Culture in the Middle Ages. Trans. Arthur Goldhammer. London: University of Chicago Press, 1982.

Lewis, Celia M. “Acceptable Lessons, Radical Truths: Mélusine as Literature for Medieval Youth". Children's Literature 39 (2011): 1-32.

Lysaght, Patricia. The Banshee. Dublin: Glendale Press, 1986.

Mac Cana, Proinsias. Celtic Mythology. Feltham: Newnes Books, 1983 (1968).

Mac Cana, Proinsias. "The Irish Analogues of Mélusine" Islanders and Water-Dwellers. Ed. P. Lysaght et al. Blackrock: Four Courts Press, 1999. 149-64.

Mac Cionaoith, Maeleachlainn. Seanchas Rann na Feirste. Baile Átha Cliath: Coisceim, 2005.

Nagy, Joseph Falaky. "Hierarchy, Heroes and Heads: Indo-European Structures in Greek Myth". Approaches to Greek Myth. Ed. L. Edmunds. Baltimore: The Johns Hopkins University Press, 1990. 199-238.

Ní Dhomhnaill, Nuala. "Dinnsheanchas: The Naming of High or Holy Places": Selected Essays. Ed. O. Frawley. Dublin: New Island, 2005. 25-42.

Ó Catháin, Séamas. "Súil siar ar Scéim na Scol 1937-1938”. Sinsear 5 (1988): 19-30.

Ó Catháin, Séamas. "The Irish Folklore Archive". History Workshop 31 (Spring 1991): 145-8.

Ó Cróinín, Dáibhí. Early Medieval Ireland 400-1200. Harlow: Longman, 1995.

Ó Danachair, Caoimhín. "Oral Tradition and the Printed Word". Irish University Review 9. 1 (Spring 1979): 31-41.

Ó Duilearga, Séamus. "Editorial Note”. Béaloideas 2.3 (1930): 252.

Ó hEochaidh, Seán. "Sídhe-Scéalta”. Béaloideas 23 (1954): 135-229 (161-6).

Ó hEochaidh, Seán. Síscéalta ó Thír Chonaill. Fairy Legends from Donegal, Irish texts Ed. S. Ó Catháin, English trans. M. Mac Neill. Dublin: Comhairle Bhéaloideas Eireann, 1977.

Ó Fiannachta, Pádraig. "Migratory Legends in Medieval Irish Literature: Third Response to Dáithí Ó hÓgáin's Paper". Béaloideas 60-1: 89-92.

Ó hÓgáin, Dáithí. The Lore of Ireland. Cork: The Collins Press, 2006.

O’Rahilly, Cecile. Táin Bó Cúalnge from the Book of Leinster. Dublin: Dublin Institute for Advanced Studies, 1967.

Ó Súilleabháin, Seán. A Handbook of Irish Folklore. Detroit: Singing Tree Press 1970 (1942).

Ó Súilleabháin, Seán and Reidar Th. Christiansen. The Types of the Irish Folktales. Helsinki: Academia Scientiarum Fennica, 2002 (1963).

Ó Súilleabháin, Seán. The Folklore of Ireland. New York: Batsford, 1974.

Ó Súilleabháin, Seán. "Irish Oral Tradition”. A View of the Irish Language. Ed. B. Ó Cuív. Dublin: Stationery Office, 1969. 47-56.

Péporté, Pit. Constructing the Middle Ages: Historiography, Collective Memory and NationBuilding in Luxembourg. Leiden: Brill, 2011.

Petrie, George. "The Castle and Lake of Inchiquin, County of Clare". The Irish Penny Journal 1 (October $\left.17^{\text {th }} 1840\right): 121-3$.

Powell, Barry B. Classical Myth. Upper Saddle River, New Jersey: Prentice Hall, 2007 (2001).

Raftery, Barry. Pagan Celtic Ireland. London: Thames and Hudson, 2000 (1994).

Soverino, Tiziana. Inscribed in the Landscape. PhD Diss., University College Dublin, 2015. 2 Vols.

Stokes, Whitley. "The Bodleian Dinnshenchas". Folklore 3 (1892): 467-516.

Stokes, Whitley. "The Edinburgh Dinnshenchas". Folklore 4 (1893): 473-97. 
Stokes, Whitley. "The Prose Tales in the Rennes Dindshenchas I and II". Revue Celtique 15 (1894): 277-336; 418-84.

Stokes, Whitley. "The Prose Tales in the Rennes Dindshenchas III and IV". Revue Celtique 16 (1895): 31-83; 135-67.

Tangherlini, Timothy R. “'It Happened Not Too Far from Here...': A Survey of Legend Theory and Characterization". Western Folklore 49.4 (1990): 371-390.

Toner, Gregory. "Macha and the Invention of Myth". Ériu 60 (2010): 81-109.

Údaras na Gaeltachta. "Cork”. 5 April 2020. http://www.udaras.ie/en/an-ghaeilge-anghaeltacht/an-ghaeltacht/corcaigh/.

Urban, Misty Rae. Monstrous Women in Middle English Romance. PhD Diss., Cornell University, 2008.

Urban, Misty, Deva F. Kemmis and Melissa Ridley Elemes (Eds). Mélusine's Footprint. Leiden: Brill, 2017.

Valk, Ülo and Sävborg, Daniel. Storied and Supernatural Places. Helsinki: Finnish Literature Society, Studia Fennica Folkloristica 23, 2018.

Walsh, E. "The Lonely Lady." Ireland's Own 71 (May 21 $1^{\text {st }} 1938$ ): 10.

Wansbrough, Henry. The New Jerusalem Bible. London: Darton Longman \& Todd, 1985.

Received: 1 November $2018 \quad$ Revised version accepted: 29 January 2019

Tiziana Soverino is an Irish Folklore teacher at Crumlin College of Further Education in Dublin. She holds an interdisciplinary PhD in Irish Folklore and Early Irish and an MLitt in Irish Folklore, both from University College Dublin. Her research interests include folk medicine, festivals, place-lore, social justice and open education. Her publications include an article on place-names about Fionn Mac Cumaill in Landscape and Myth in North-Western Europe (2019) and an article on toothache cures in the Journal of the History of Dentistry (2018).

tizianasireland@gmail.com 